\title{
SKRINING BAKTERI SIMBION PADA LALAT BUAH (Drosophilla melanogaster) SEBAGAI KANDIDAT PENGHASIL SENYAWA ANTIBIOTIKA
}

\author{
Armini Syamsidi ${ }^{1}$, Arni Fitriyanti ${ }^{2}$ \\ ${ }^{1}$ Farmasi, FMIPA, UniversitasTadulako \\ email: armini.syamsidi@gmail.com \\ ${ }^{2}$ Farmasi, Universitas Hasanuddin \\ email: arni.fitriyanti@gmail.com
}

\begin{abstract}
Now the emergence of bacterial resistance to antibiotics is a national and global issues that have a significant impact on public health. We report the screening of bacterial symbionts in fruit flies (Drosophilla melanogaster) as a producer of new antibiotic compounds. This study aims to get antibiotic-producing bacterial symbionts in fruit flies (Drosophilla melanogaster). In this study used methods of isolation, purification and antibacterial testing using four test bacteria (Escherichia coli, Staphylococcus aureus, Bacillus subtilis, and Salmonella thyposa). Isolation of fruit flies (Drosophilla melanogaster) that uses peptone solution prepared dilutions to 10-9 and then purification is done by scraping the bacteria on NA medium by repeatedly to obtain pure isolates and subsequently antibacterial test. The results showed that the bacterial isolation 10-8 and 10-9 dilutions allegedly produce antibiotic-producing compound while the antibacterial test using test bacteria showed that the compound obtained from the insulation in the fruit fly (Drosophilla melanogaster) showed the compound to inhibit the growth of bacteria Escherichia coli and Staphylococcus aureus.
\end{abstract}

Keywords: fruit flies, Drosophilla melanogaster, antibiotics

\begin{abstract}
ABSTRAK
Munculnya resistensi bakteri terhadap antibiotika saat ini merupakan masalah nasional dan global yang memiliki dampak signifikan bagi kesehatan masyarakat. Telah dilakukan penelitian mengenai skrining bakteri simbion pada lalat buah (Drosophilla melanogaster) sebagai penghasil senyawa antibiotika baru. Penelitian ini bertujuan untuk mendapatkan bakteri simbion penghasil antibiotika pada lalat buah (Drosophilla melanogaster). Pada penelitian ini digunakan metode isolasi, pemurnian dan pengujian antibakteri dengan menggunakan 4 bakteri uji (Escherchia coli, Staphylococcus aureus, Bacillus subtilis, dan Salmonella thyposa). Isolasi lalat buah (Drosophilla melanogaster) yang menggunakan larutan pepton yang dibuat pengenceran sampai 10-9 kemudian pemurnian yang dilakukan dengan menggoreskan bakteri pada medium NA dengan berulang kali sampai mendapatkan isolat murni dan selanjutnya dilakukan uji antibakteri. Hasil isolasi bakteri memperlihatkan bahwa pada pengenceran 10-8 dan 10-9 diduga menghasilkan senyawa penghasil antibiotika sedangkan pada uji antibakteri dengan menggunakan bakteri uji memperlihatkan bahwa senyawa yang diperoleh dari hasil isolasi pada lalat buah (Drosophilla melanogaster) memperlihatkan senyawa tersebut dapat menghambat pertumbuhan bakteri Escherchia coli dan Staphylococcus aureus.
\end{abstract}

Kata kunci: lalat buah, Drosophilla melanogaster, antibiotika 


\section{PENDAHULUAN}

Munculnya resistensi bakteri terhadap antibiotika saat ini merupakan masalah nasional dan global yang memiliki dampak signifikan bagi kesehatan masyarakat. Dalam sebuah jurnal penelitian dicantumkan bahwa terdapat kekebalan yang tinggi terhadap antibiotika yang paling banyak digunakan. Untuk Escherichia coli, tingkat kekebalan yang tinggi dijumpai terhadap ampicillin dan cotrimoxazole.Di Negara-negara Eropa monitoring terhadap penggunaan antibiotika sudah dilakukan secara rutin dan karena terbukti memberikan dampak negatif, maka muncul larangan terhadap penggunaan antibiotika. Berawal dari diketahuinya bakteri yang resisten terhadap tetrasiklin, dimana tetrasiklin merupakan antibakteri yang paling banyak digunakan di Eropa $(1,2)$.

Sehingga dari sinilah timbul daya dorong untuk melakukan pencarian senyawa-senyawa baru, terhadap antibiotika yang sudah resisten.Dalam penelitian ilmu kedokteran ditemukan bahwa selain lalat membawa kuman penyakit. Ternyata dalam tubuh lalat tersebut juga mengandung zat antibiotika yang mampu membunuh kuman. Salah satu hadis (Shahih al-Bukhari) menyatakan bahwa salah satu sayapnya terdapat penyakit dan pada sayap yang satunya lagi terdapat obat. Sehingga program skrining perlu direncanakan untuk menentukan bahan yang mungkin efektif untuk pengobatan infeksi yang sampai saat ini telah resisten terhadap bahan kemoterapeutika, maupun untuk memperoleh terapi yang aman dan lebih cepat terhadap suatu infeksi (3).

Dalam lingkungan sekitar tidak dipungkiri kita seringnya berinteraksi dengan lalat, Telah dilakukan isolasi dan identifikasi bakteri dari lalat buah, dengan mengidentifikasi total 18 spesies bakteri yang berbeda family: Enterobacteriaceae, Pseudomonadaceae, Vibrionaceae,

Micrococcaceae,
Bacillaceae, dan Listeria genus. Ditemukan koloni baru seperti: Cereus basillus, Enterobacter sakazakii, stuartii providencia, dan Pseudomonas aeruginosa. Selain itu telah diidentifikasi mikroba usus larva, dikumpulkan dari Lalat selanjutnya 12 strain bakteri diisolasi diuji ketahanan atau sensitivitas sampai 23 yang umum digunakan antibiotik. Sembilan dari 14 isolat yang telah diidentifikasi sebagai rettgeri Providencia. Providencia spp adalah agen umum infeksi nosokomal dan sekarang digunakan sebagai refraktori untuk pengobatan diberikan antibiotik, desinfektan, dan topical berat $(4,5)$.

Adapun penelitian tentang isolasi Salmonella dan spesies Shigella dari lalat rumah. Selain Lalat rumah (Musca domestica $L$ ) lalat buah yang berfamili Tephritidae tidak sama dengan lalat rumah, lalat buah ini biasa ditemukan pada buah yang hampir masak. Sehingga menyebabkan buah menjadi busuk sebelum masak atau mencapai kematangan $(6,7)$.

Berdasarkan hal tersebut diatas bahwa kemungkinan bakteri simbion yang terdapat pada lalat buah dapat menghasilkan antibotika baru, maka permasalahan yang timbul adalah apakah bakteri simbion yang terdapat pada lalat buah dapat berpotensi mengasilkan antibiotika.

Tujuan dari penelitian ini adalah untuk mendapatkan bakteri simbion penghasil antibiotika pada lalat buah.

\section{METODE PENELITIAN}

Alat dan bahan yang digunakan adalah oven, autoklaf, laminar air flow, inkubator, lemari pendingin, timbangan analitik, mikroskop, pipet mikro, cawan petri, tabung reaksi, ose bulat, , botol pengencer, dan lampu spiritus, air steril, Pepton, medium nutrient agar (NA), bakteri uji Escherchia coli, Staphylococcus aureus, Bacillus subtilis, dan Salmonella thyposa, kertas $\mathrm{pH}$, 
aluminium foil, paper dick, $\mathrm{NaCl}$ fisiologis, dan kapas.

Alat-alat yang digunakan dicuci dengan deterjen, kemudian dibilas dengan air dan dikeringkan. Alat-alat gelas disterilkan menggunakan oven pada suhu $180^{\circ} \mathrm{C}$ selama 2 jam. Untuk alat-alat logam disterilkan dengan cara dipijarkan dengan menggunakan bunsen dan alatalat yang terbuat dari karet dan plastik serta alat-alat ukur disterilkan dengan aoutoklaf pada suhu $121{ }^{\circ} \mathrm{C}$ selama 15 menit.

\section{Pembuatan Larutan Pengencer}

Dibuat larutan pepton $0,5 \%$ dengan cara terlebih dahulu ditimbang pepton sebanyak $0,5 \mathrm{~g}$ kemudian dilarutkan dengan menggunakan air steril hingga $100 \mathrm{~mL}$ dan disterilkan dengan menggunakan aoutoklaf sampai suhu mencapai $121^{\circ} \mathrm{C}$ selama 15 menit.

\section{Isolasi Bakteri Pengahasil Antibiotika dari Lalat}

Sampel lalat buah dimasukkan kedalam larutan Pepton 0,5 \% yang sudah terdapat dalam botol pengencer dan dicukupkan dengan air suling steril hingga $10 \mathrm{~mL}$ (pengenceran $10^{-1}$ ). Suspensi sampel dari pengenceran $10^{-1}$ kemudian dibuat pengenceran sampai $\begin{array}{lll}\text { pengenceran } & 10^{-9} \text {. } & \text { Kemudian }\end{array}$ diinokulasikan kedalam media NA dengan metode tuang secara aseptis, diinkubasi selama $7 \times 24$ jam dan diamati koloni yang mempunyai zona bening disekitarnya.

\section{Pemurnian bakteri}

Setelah didapatkan koloni yang mempunyai zona bening disekitarnya, ini yang diambil untuk dimurnikan. Disiapkan medium NA steril selanjutnya didinginkan sampai suhu $45{ }^{\circ} \mathrm{C}$, dibiarkan sampai memadat. digoreskan biakan bakteri dengan menggunakan ose steril. diinkubasi selama $1 \times 24$ jam. Untuk mendapatkan isolat murni dilakukan penggoresan secara berulang-ulang kali sampai mendapatkan isolat yang betulbetul terpisah.

\section{Skrining Bakteri Penghasil Antibiotika dari Lalat}

Isolat bakteri murni yang telah diperoleh kemudian diremajakan ke dalam medium NA dan di inkubasi selama $4 \times 24$ jam. digoreskan beberapa bakteri seperti Escherchia coli, Staphylococcus aureus, Bacillus subtilis, dan Salmonella thyposa.diinkubasi selama $1 \times 24$ jam.

\section{Identifikasi Isolat Bakteri penghasil Antibiotika dari Lalat}

\section{A. Pengamatan Makroskopik}

Sifat koloni suatu mikroorganisme adalah sifat yang mempunyai sangkut paut dengan bentuk, susunan, pertumbuhan, pengkilatan dan sebagainya suatu koloni mikroorganisme. Pengamatan ini dapat dilakukan dengan pandangan biasa.

\section{B. Pewarnaan Gram}

Pertama objek glass dibersihkan dengan alkohol,diambil 1 ose biakan dan diratakan. Setelah itu difiksasi. Setelah dingin diteteskan cat gram A (kristal violet) 2-3 tetes dan dibiarkan 1 menit kemudian dicuci dengan air mengalir dan dikeringkan. Ditetesi larutan gram B (larutan mordant) 2-3 tetes dibiarkan selama 1 menit kemudian dicuci dengan air mengalir dan dikeringkan. Ditetesi lagi larutan gram $C$ (alkohol asam) 2-3 tetes dan dibiarkan selama 30 detik kemudian dicuci lagi dengan air mengalir dan dikeringkan. Yang terakhir ditetesi dengan larutan gram D (safranin) 2-3 tetes dan dibiarkan selama 30 detik kemudiam dicuci lagi dan dikeringkan. Lalu diamati di bawah mikroskop dengan perbesaran $10 \times 10$ atau perbesaran $10 \times 40$. 


\section{Uji Biokimia}

\section{Uji Fermentasi Karbohidrat}

Disiapkan 3 tabung reaksi lalu masing-masing tabung diisi medium LB (Lactosa Broth) pada tabung I, medium GB (Glucosa Broth) pada tabung II, dan medium SB (Sucrosa Broth) dalam tabung III. Masukkan tabung durham ke dalam masing-masing tabung lalu ditutup kapas. Diinokulasikan biakan ke dalam masing-masing tabung secara aseptis, semua tabung diinkubasi selama $2 \times 24$ jam dengan suhu $37{ }^{\circ} \mathrm{C}$. Masing-masing tabung diamati perubahan yang terjadi.

\section{Uji Persyaratan Oksigen}

Medium thioglycolate dimasukkan

ke dalam tabung reaksi yang diinokulasikan suspensi biakan sebanyak $1 \mathrm{~mL}$. Diinkubasi pada suhu $28-32{ }^{\circ} \mathrm{C}$ selama $4 \times 24$ jam. Pengamatan dilakukan dengan melihat pertumbuhan pada permukaan medium.

\section{Uji Methyl Red (MR)}

Dimasukkan medium MRPV kedalam tabung reaksi secara aseptis, diinokulasikan dengan biakan mikroba dan diinkubasi pada suhu $37{ }^{\circ} \mathrm{C}$ selama 24 jam kemudian ditetesi dengan merah metil. Adanya perubahan warna medium menjadi merah menunjukkan mikroba tersebut memproduksi asam.

\section{Uji Voges Preskauer}

Biakan mikroba dalam medium MRVP ditambahkan dengan reagen barrit yaitu 10 tetes larutan A dan 10 tetes larutan B, dikocok selama 30 detik. Positif jika warna merah.

\section{Uji Penggunaan Sitrat}

Medium SCA dibuat agar miring dan diinokulasikan dengan biakan secara goresan, kemudian diinkubasi pada suhu $37{ }^{\circ} \mathrm{C}$ selama 24 jam. pengamatan dilakukan dengan melihat adanya pertumbuhan dan mengubah warna hijau menjadi biru.

\section{Uji Katalase}

Gelas objek ditetesi dengan dua tetes hidrogen peroksida $3 \%$ kemudian secara aseptik diinokulasi dengan biakan dan dicampur dengan baik. Uji (+) ditandai dengan terbentuknya gelembung udara.

\section{Uji Hidrolisis Gelatin}

Dimasukkan medium gelatin kedalam tabung reaksi secara aseptis, diinokulasikan biakan setelah itu diinkubasi selama $2 \times 24$ jam dengan suhu $37{ }^{\circ} \mathrm{C}$, setelah diinkubasi biakan dimasukkan kedalam kulkas selama 1530 menit agar medium memadat, amati perubahannya.

\section{Uji Motilitas}

Masukkan medium MRVP kedalam tabung reaksi secara aseptis, diinokulasikan biakan dan diinkubasi selama $2 \times 24$ jam dengan suhu $37{ }^{\circ} \mathrm{C}$, amati perubahan yang terjadi.

\section{Uji Kighler Iron Agar}

Medium TSIA dibuat agar miring dan diinokulasikan dengan biakan mikroba secara goresan ke dalam dasar medium kemudian keseluruhan permukaannya. Selanjutnya diinkubasi selama 18-24 jam pada suhu $37{ }^{\circ} \mathrm{C}$. pembacaan hasil berdasarkan terjadinya fermentasi dengan permukaan warna pada dasar dan lereng pada media serta ada tidaknya pembentukan gas $\mathrm{H}_{2} \mathrm{~S}$ pada media.

\section{Pengaruh pH}

Disiapkan tiga tabung dengan $\mathrm{pH}$ yang berbeda yaitu $\mathrm{pH} 5,0 ; 7,0$; dan 9,0 ditambahkan medium Nutrient broth diinokulasikan tabung pertama $(\mathrm{pH} \mathrm{5,0)}$ dengan biakan yang sudah ada. lakukan hal yang sama untuk tabung kedua $(7,0)$ dan tabung ketiga $(9,0)$ disimpan pada suhu kamar selama 48 jam kemudian dilihat derajat kekeruhan pertumbuhan bakteri. 


\section{E. Pengaruh Suhu}

Disiapkan tiga tabung kemudian dilabeli suhu yang akan diinkubasi yaitu pada suhu $28{ }^{\circ} \mathrm{C}, 37{ }^{\circ} \mathrm{C}$ dan $45{ }^{\circ} \mathrm{C}$ yang telah berisi medium Nutrient broth, dimasukkan isolat yang sudah diencerkan dipipet $1 \mathrm{~mL}$ kedalam tabung setelah itu ditumbuhkan selama 48 jam. Dikocok ketiga tabung dan dibandingkan derajat kekeruhannya.

\section{HASIL DAN PEMBAHASAN}

Mengisolasi bakteri yang terdapat pada lalat dengan membiakkan pada larutan pepton $0,5 \%$ dan dilakukan pengenceran sampai $10^{-9}$. Selanjutnya semua hasil pengenceran diinokulasikan ke dalam media NA dan diinkubasi selama 7x24 jam kemudian diamati koloni dengan zona bening disekitarnya.

Hasil pengenceran yang memperlihatkan pertumbuhan koloni pada pengenceran $10^{-8}$ dan $10^{-9}$.

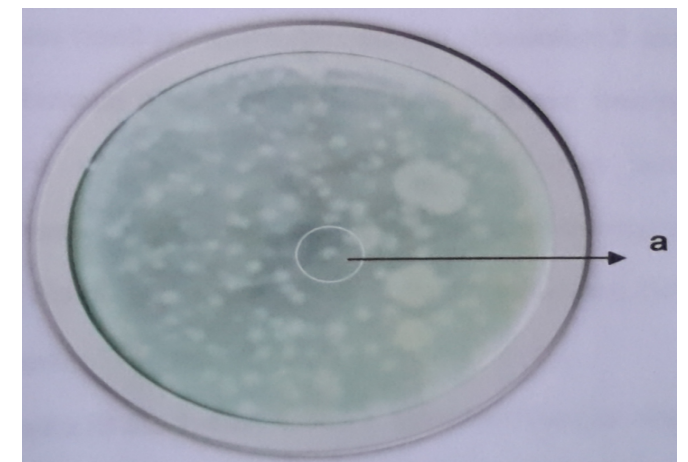

Gambar 1. Hasil isolasi bakteri simbion lalat pada pengenceran $10^{-8}$ untuk isolate BSL-1 diinkubasi selama $7 \times 24$ jam

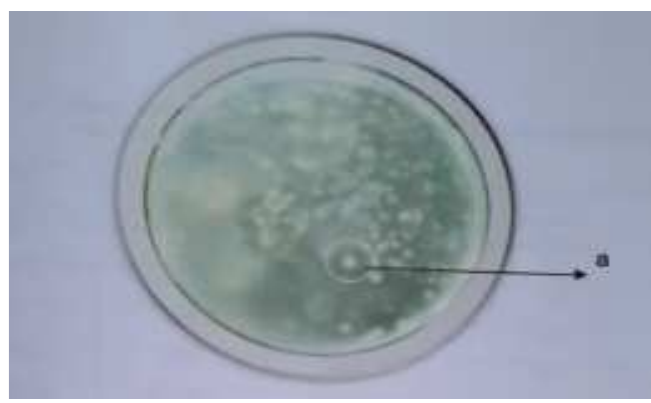

Gambar 2. Hasil isolasi bakteri simbion lalat pada pengenceran $10^{-8}$ untuk isolate BSL-1 diinkubasi selama $7 \times 24$ jam
Berdasarkan hasil pengamatan diperoleh 2 isolat yang tumbuh disekitar koloni bakteri yang memperlihatkan zona bening pada medium agar. Selanjutnya dilakukan pemurnian isolat dan dilakukan uji efek antibakteri penghasil anbiotika dari lalat, dengan menggunakan beberapa bakteri uji seperti, Escherchia coli, Staphylococcus aureus, Basillus subtilis, dan Salmonella thyposa.

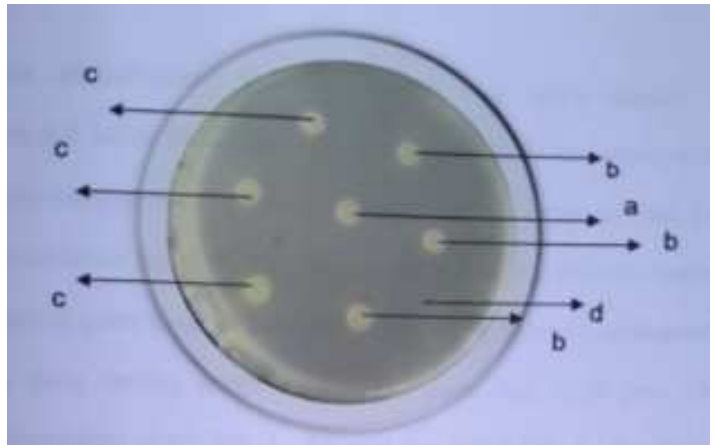

Gambar 3. Hasil uji daerah hambat bakteri lalat terhadap bakteri uji Staphylococcus aureus pada inkubasi $2 \times 24$ jam

Keterangan: $\quad a=$ Kontrol positif (ampisilin), $\mathrm{b}=$ isolat BSL-2, $\mathrm{c}=$ isolat BSL-1, $\mathrm{d}=$ bakteri uji Staphylococcus aureus.

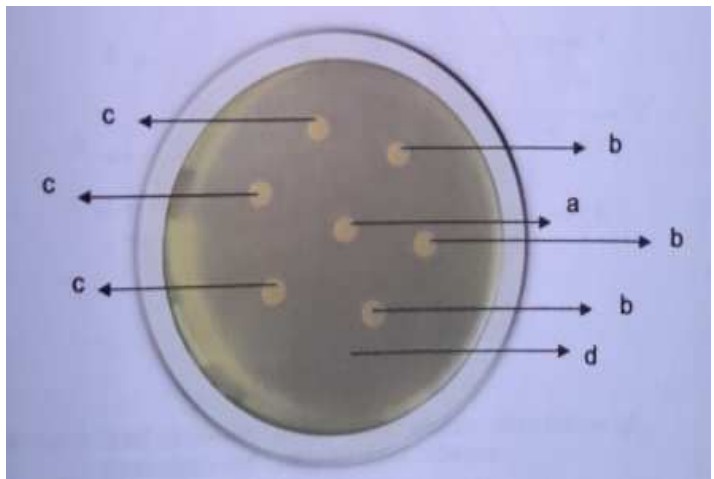

Gambar 4. Hasil uji daerah hambat bakteri lalat terhadap bakteri uji Bacillus subtilis pada inkubasi $2 \times 24$ jam

Keterangan: $\mathrm{a}=$ Kontrol positif (ampisilin), $\mathrm{b}=$ isolat BSL-2, $\mathrm{c}=$ isolat BSL-1, $\mathrm{d}=$ bakteri uji Bacillus subtilis. 


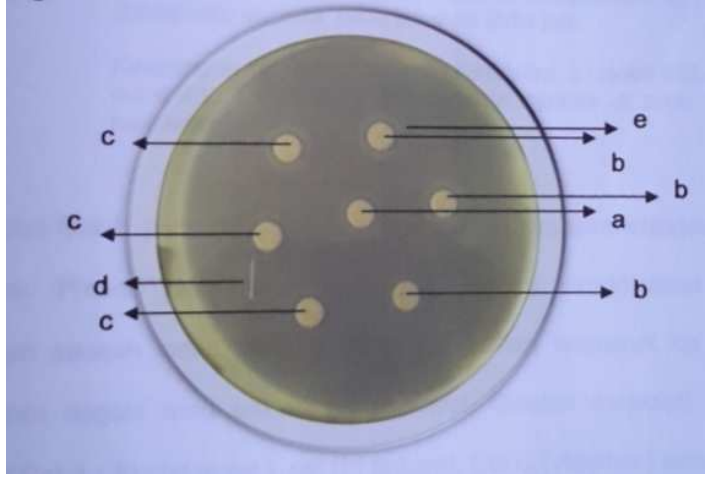

Gambar 5. Hasil uji daerah hambat bakteri lalat terhadap bakteri uji Escherchia coli pada inkubasi $2 \times 24$ jam

Keterangan: $\mathrm{a}=$ Kontrol positif (ampisilin), $\mathrm{b}=$ isolat BSL-2, $\mathrm{c}=$ isolat BSL-1, $\mathrm{d}=$ bakteri uji Escherchia coli, e = zona hambat

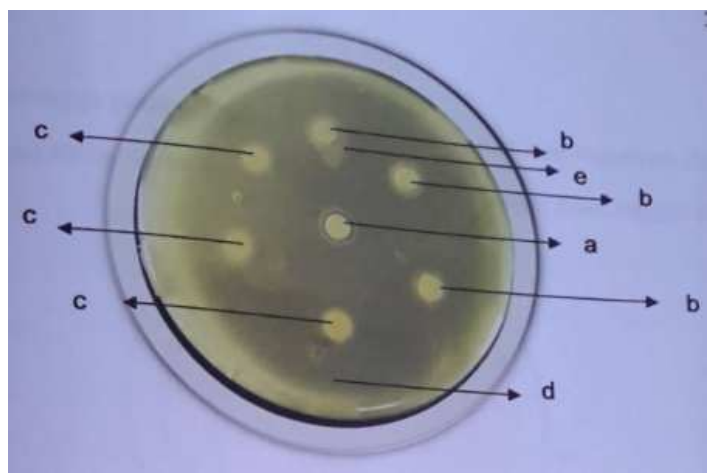

Gambar 6. Hasil uji daerah hambat bakteri lalat terhadap bakteri uji Salmonella thyposa pada inkubasi $2 \times 24$ jam

Keterangan: $\mathrm{a}=$ Kontrol positif (ampisilin), $\mathrm{b}=$ isolat BSL-2, $\mathrm{c}=$ isolat BSL-1, $\mathrm{d}=$ bakteri uji Salmonella thyposa, e = zona hambat keruh

2 isolat (BSl-1 dan BSL-2) hanya dapat menghambat bakteri uji gram negatif seperti Escherchia coli dan Salmonella thyposa yang dibandingkan dengan penghambatan menggunakan ampicilin. Hasil selengkapnya dapat dilihat pada tabel 1 dan 2 .
Tabel 1 Hasil pengukuran Daerah Hambat dari hasil fermentasi terhadap mikroba uji Escherchia coli

\begin{tabular}{|c|c|c|c|}
\hline \multirow[b]{2}{*}{ Replikasi } & \multicolumn{2}{|c|}{ Isolat (mm) } & \multirow{2}{*}{$\begin{array}{c}\text { Kontrol } \\
\text { Ampisilin } \\
20 \mu \mathrm{g}\end{array}$} \\
\hline & BSL-1 & BSL-2 & \\
\hline 1 & 9,7 & 8,8 & 8,3 \\
\hline 2 & 10,7 & 7,7 & 7,2 \\
\hline 3 & 9,2 & 8,1 & 8,4 \\
\hline Jumlah & 29,6 & 24,6 & 23,9 \\
\hline $\begin{array}{c}\text { Rata-rata } \\
+ \text { Nilai } \\
\text { SD }\end{array}$ & $\begin{array}{c}9,6 \pm \\
0,8\end{array}$ & $\begin{array}{c}8,2 \pm \\
0,6\end{array}$ & $8,0 \pm 0,7$ \\
\hline
\end{tabular}

Tabel 2 Hasil pengukuran Daerah Hambat dari hasil fermentasi terhadap mikroba uji $S$. thyposa

\begin{tabular}{cccc}
\hline \multirow{2}{*}{ Replikasi } & \multicolumn{2}{c}{ Isolat (mm) } & Kontrol \\
\cline { 2 - 3 } & BSL-1 & BSL-2 & $\begin{array}{c}\text { Ampisilin } \\
20 \mu \mathrm{g}\end{array}$ \\
\hline 1 & 8,3 & 9,6 & 14,3 \\
2 & 8,9 & 9,3 & 14,5 \\
3 & 8,3 & 7,9 & 13,6 \\
Jumlah & 25,5 & 26,8 & 42,4 \\
Rata-rata & $8,6 \pm$ & $8,9 \pm$ & $14,1 \pm 0,5$ \\
+ Nilai & 0,3 & 0,9 & \\
SD & & & \\
\hline
\end{tabular}

Kedua isolat yang diperoleh tersebut selanjutnya dikarakterisasi dan diidentifikasi. Proses pengecatan gram pada tahap karakterisasi untuk menentukan isolat tersebut termasuk gram negatif dan positif. Setelah melewati proses pemberian cat A (Kristal violet), cat B (iodium), cat C (alkohol) dan cat D (safranin), diperoleh isolat BSL-1 termasuk golongan gram negatif berbentuk batang (basil) sedangkan BSL2 berbentuk bulat (coccus) yang ditunjukkan pada mikroskop yaitu bakteri berwarna merah. Hal ini disebabkan bakteri gram negatif mempunyai kandungan lipid yang tinggi, lipid ini akan larut dalam alcohol dan aseton yang digunakan sebagai larutan pemucat, sehingga pori-pori dinding sel membesar dan meningkatkan daya larut kompleks Kristal violet-iodium pada dinding sel bakteri gram negatif. 


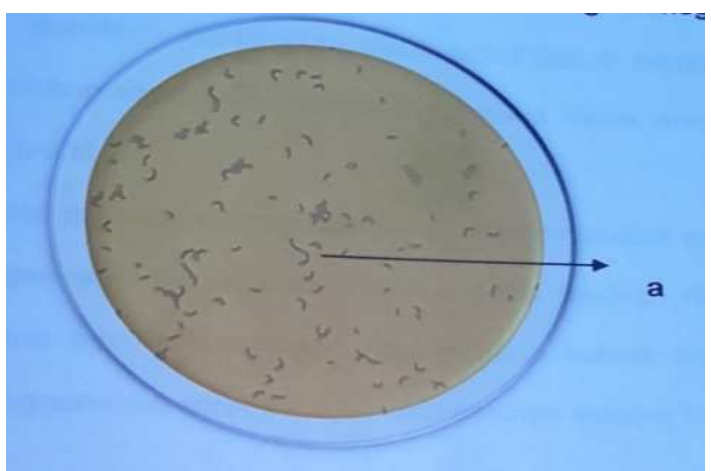

Gambar 7. Hasil pengamatan mikroskopik pembesaran 40x pada isolat BSL-1 berbentuk batang (basil)

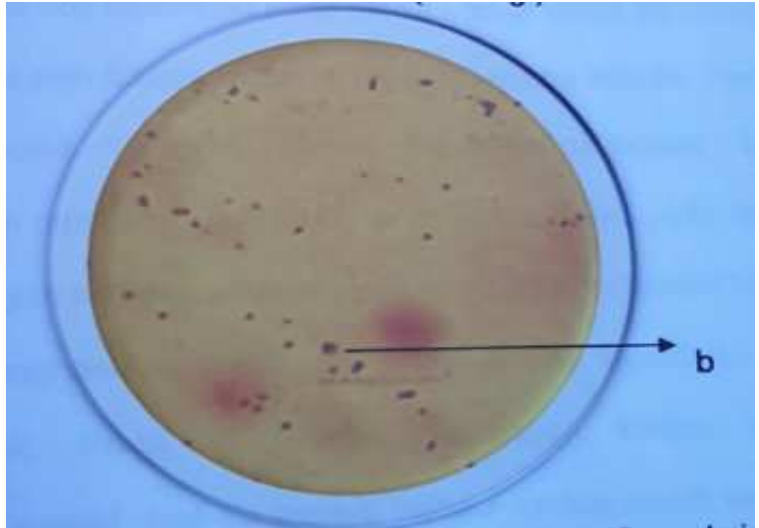

Gambar 8. Hasil pengamatan mikroskopik pembesaran $40 \mathrm{x}$ pada isolat BSL-2 berbentuk bulat (coccus)

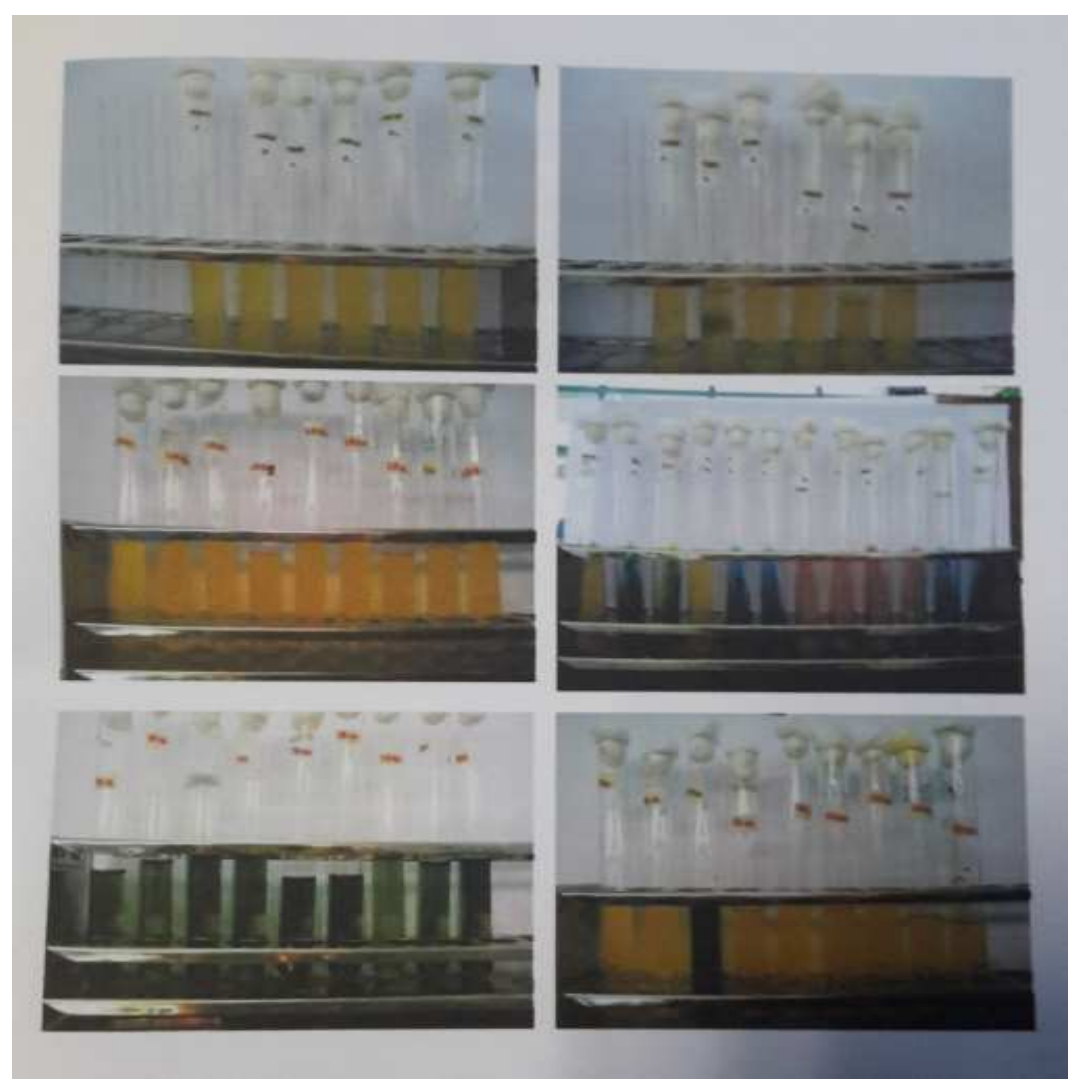

Gambar 9. Foto hasil tes biokimia dengan berbagai media karakterisasi untuk isolat BSL-1 dan BSL-2

Karakterisasi dengan media Triple Sugar Iron Agar, isolat BSL-1 menghasilkan reaksi asam pada lereng media dan pada dasar media, tidak menghasilkan gas dan $\mathrm{H}_{2} \mathrm{~S}$. sedangkan isolat BSL-2 menghasilkan reaksi basa pada lereng media dan reaksi asam pada dasar media, tidak menghasilkan gas dan $\mathrm{H}_{2} \mathrm{~S}$.
Pada uji sitrat menunjukkan bahwa kedua isolat tersebut positif. Hal ini dibuktikan dengan adanya perubahan warna pada medium dari warna hijau menjadi warna biru. Hal tersebut menandakan bahwa kedua BSL tersebut dapat menggunakan sitrat sebagai satusatunya sumber karbon dan energi. 
Pada uji metal red diperoleh hasil yaitu kedua isolat memberikan hasil positif yang ditandai perubahan medium menjadi warna merah. Hal ini berarti kedua isolat tersebut dapat memfermentasikan karbohidrat menghasilkan asam campuran. Uji indol menunjukkan hasil yaitu isolat BSL-1 positif ditandai dengan terbentuknya cincin merah. Hal ini menunjukkan bahwa isolat BSL-1 dapat menghasilkan indol dari asam amino triprofan sedangkan isolat BSL-2 tidak. Pada uji vogest proskauer, kedua isolat tidak menunjukkan hasil positif, berarti kedua isolat tersebut tidak dapat menghasilkan 2,3 butanadiol.

Pada uji karbohidrat diperoleh hasil BSL-1 dapat memfermentasikan sukrosa, laktosa dan glokosa sedangkan isolat BSL-2 hanya dapat memfermentasikan glukosa dan laktosa. Hal ini dibuktikan dengan adanya perubahan warna pada medium dari hijau menjadi kuning dan timbulnya gelembung gas pada tabung durham. Untuk uji hidrolisis pati, kedua isolat tersebut memberikan hasil positif. Hasil selengkapanya dapat dilihat pada gambar 9.

\section{KESIMPULAN}

Berdasarkan Berdasarkan hasil pengamatan dan analisa statistik dapat disimpulkan bahwa :

1. Diperoleh 2 isolat bakteri simbion (BSL-1 dan BSL-2) pada lalat sebagai kandidat penghasil antibiotika terhadap bakteri uji Escherchia coli

2. Hasil karakterisasi pada isolat BSL-1 BSL-1 berupa gram negatif berbentuk basil (batang), suhu optimal $37^{\circ} \mathrm{C}$ dan $\mathrm{pH}$ optimal 7 dan dapat memfermentasikan sukrosa, glukosa dan latosa, sedangkan BSL-2 berupa gram negatif berbentuk kokus (bulat), suhu optimal $37^{\circ} \mathrm{C}$ dan $\mathrm{pH}$ optimal 7 dan hanya dapat memfermentasikan glukosa dan laktosa.

\section{UCAPAN TERIMA KASIH}

Terima kasih kepada Dikti yang menjadi sponsor dalam penyediakan dana untuk penelitian ini.

\section{DAFTAR PUSTAKA}

1. Anpalahan $\mathrm{M} \&$ Darzins $P$. Vancomycin Resistant Enterococcus ingeriatrichospitals and long term care facilities: implications for practitioners. Australian Journal on Ageing. Vol. 20. 2001. No.2.pp.100102. [diakses 13 Mei 2010]

2. Baker E. Handbook of Bacteriological Technique. Second Edition. West Minter Medical School. London. Hal : 67-75

3. Buchanan RE, Gibbons NE. Bergey's Manual Of Determinative Bacteriology, Eight Edition, Williams and Wilkins Company, Baltimore. 1974

4. Djide MN dan Sartini. Mikrobiologi Farmasi Dasar. Lembaga Penerbitan Universitas Hasanuddin. Makassar. 2008. Hal. 81-84, 247, 246, 322-323

5. Dana RK, dan Jacob M. Nature Antibiotic Resistance of Bacteria Isolated from Larvae Oil Fly Helaeomyia petrolei. Sekolah Ilmu Hayati. Universitas Nebraska. Lincoln. 13 Maret 2000 [diakses 29 April 2010]

6. Darmawayasa IBG. Isolasi dan Identifikasi Bakteri Pendegradasi Lipid (lemak) pada Beberapa Tempat Pembuangan Limbah dan estuary DAM Denpasar. Laboratorium Mikrobiologi Jurusan Biologi FMIPA. Universitas Udayana. Jurnal Bumi Lestari. Vol 8. No 2. Agustus 2008. Hal 122-127 [diakese 17 Januari 2011]

7. Ghislain F. Antibiotic Resistance In The EU-Science, Politics, and Policy. AgBioForum-Vol 3, Number $2 \& 3$. Pages 148-155. [diakses 13 Mei 2010] 
8. Khalsoven. Laboratorium Data. Balai Penelitian Tanaman Jeruk dan Bali Subropika. The Pests od Crops in Indonesia. PT Ichtiar Baru-Van Hoeven. Jakarta. 1981. Hal. 701

9. Lyudmila VK, dan Miller JP. Isolation and Identification of Bacteria Assosiated with Adult Laboratory Mexican Fruit Flies. Current Microbiology An International Journal Springer-Verlag New York, vol.42.2001.Pp 290-294. [diakses 29 April 2010].
10. Ugbogu OC dan Nwachukwu NC. Isolation of Salmonella and Shigella species from house flies. African Journal of Biotechnologu Vol. 5, no.11. pp. 1090-1091. 2 June 2006. [diakses 29 April 2010]. Available online

at http://www.academicjournals.org/AJ $\underline{B}$ 